\title{
Removal of Suspended Particles by Fouling Communities*
}

\author{
David H. Mook \\ Harbor Branch Foundation, Inc., R. R. 1, Box 196, Fort Pierce, Florida 33450, USA
}

\begin{abstract}
Suspended particle consumption by whole fouling communities was measured with a particle counter Experimental fouling communities removed suspended particles of all sizes between 1 and $40 \mu \mathrm{m}$ with equal efficiency. Particles of certain size ranges $(1.5-5$ and $>25 \mu \mathrm{m})$ are defecated by some species; they may be made available as a food source for other species of the fouling community.
\end{abstract}

\section{INTRODUCTION}

In fouling communities the majority of the sessile animals are suspension feeders. Like all marine suspension feeders, these animals are important in altering sedimentation rates of fine suspended material by ingesting suspended material and voiding it as feces, pseudofeces or larger suspended particles (Haven and Morales-Alamo, 1966). The mechanisms by which these organisms collect suspended material from the water column have been reviewed by Jørgensen (1966) and Rubenstein and Koehl (1977); biodeposition by suspension feeders has been discussed by Haven and Morales-Alamo (1970).

Feeding efficiencies and rates have been measured for individual species of various taxonomic groups, such as bivalves (Mohlenberg and Riisgard, 1979, 1978), tunicates (Randlov and Riisgard, 1979) and salps (Harbison and McAlister, 1979). Many of these measurements were done using suspensions of algae (Mohlenberg and Riisgard, 1978, 1979; Harbison and McAlister, 1979; Randlov and Riisgard, 1979) or yeast (Riisgard, 1977), often in experimental chambers designed to assure that animals did not pass the water more than once through their filtration apparatus (Riisgard, 1977; Riisgard and Mohlenberg 1979).

Body size, temperature, food concentration and tides all influence the filtration rate of suspension feeders

- Contribution No. 231 of the Harbor Branch Foundation, Inc.
(Winter, 1978). Since the Indian River fouling communities consist of many species (Mook, in press) each one reacting differently to changes in the environment, obtaining a meaningful estimate of filtration rates on the community level may not be possible using published methods and will not be attempted in this study. Fouling communities frequently exist in areas of little $\left(<1 \mathrm{~cm} \mathrm{~s}^{-1}\right)$ water movement. Because of this slight water movement, a given amount of water is probably filtered more than once by some members of the fouling community and systems that do not allow water to be refiltered may give unrealistic results. Because of these complexities, no attempt is made to quantify particle retention efficiencies.

The purpose of this study is to determine if the fouling community selectively retains particles of certain size and if the community emits and possible recycles any suspended material.

\section{MATERIALS AND METHODS}

Fouling communities were established on $15 \times$ $15 \mathrm{~cm}$ Italian quarry tiles submerged $10 \mathrm{~cm}$ below the water surface at the Harbor Branch Foundation boat basin located north of Ft. Pierce, Florida (USA) on the Indian River lagoon. Communities were all over 1 y old and well established. Communities consisted mainly of barnacles Balanus eburneus, bryozoans (Bugula sp.), the tube building amphipod Corophium lacustre, hyd- 
roids and sponges. For a more detailed description of this fouling community see Mook $(1976,1980)$. When communities were not being used in feeding studies, they were stored on racks suspended in the boat basin.

Counts of particles in the size range $1-40 \mu \mathrm{m}$ were made with a Model TA II Coulter Counter equipped with a $100 \mu \mathrm{m}$ aperature. An oscilloscope was connected to the output of the preamplifier to detect the presence of electronic interference from other devices in the building. Only data from counts made when no electronic interference was present were recorded.

All measurements were made in circular containers containing $15 \mathrm{l}$ of water and equipped with air bubblers to generate a weak current in order to keep small particles evenly distributed while communities were in the container. Water for all studies was either taken directly from the Indian River or from a tank of filtered seawater in the laboratory. Both river water and laboratory water had salinities of about $35 \% \mathrm{~S}$ and temperatures between $20^{\circ}$ and $25^{\circ} \mathrm{C}$. Laboratory seawater was collected offshore in the Florida current and was filtered through a $5 \mu \mathrm{m}$ filter.

Experimental fouling communities were collected from the boat basin and prior to use were rinsed with running seawater to remove any loose material adhering to the community. The communities were then submerged in the experimental container (1 community per container) and initial particle counts were made after 5 min of submergence so that any particles added to the container with the community would become evenly distributed. Subsequent counts were made by taking $30 \mathrm{ml}$ samples from the container at various intervals (up to $4 \mathrm{~h}$ ) after the experiment had begun. Five replicate counts were made on each sample.

Initial studies were done by putting fouling communities in a container of Indian River water and measuring the decreases in particle counts after $1 \mathrm{~h}$ with the Coulter Counter. This procedure was repeated 5 times with different tiles during spring 1980. To determine if the communities were feeding selectively, 2 communities were removed from the boat basin, placed in filtered seawater, and starved for $2 \mathrm{~d}$ to purge their digestive systems of fecal material. The filtered seawater was replaced 4 to 5 times each day to prevent the communities from feeding on any suspended fecal material that may have accumulated in the filtered seawater. Communities were then put in separate test containers of Indian River water and particle counts were made on an hourly basis for $4 \mathrm{~h}$. Four replicates were run to ascertain if the communities were emitting particles of certain size classes. A community was taken from the boat basin and put in a test container of filtered sea water. Counts were made hourly to measure any increase in numbers of particles within certain size classes. This was repeated 3 times with differ- ent tiles. Containers filled with Indian River water (2) and filtered sea water (2) but containing no fouling community were used as controls.

\section{RESULTS AND DISCUSSION}

Controls exhibited little change in particle counts after $1 \mathrm{~h}$. Communities taken directly from the boat basin and allowed to filter river water for $1 \mathrm{~h}$ appeared to take up particles of less than $1.5 \mu \mathrm{m}$ in diameter and particles between 5 and $25 \mu \mathrm{m}$ in diameter at a greater rate than particles between 1.5 and $5 \mu \mathrm{m}$ and greater than $25 \mu \mathrm{m}$ in diameter (Fig. 1). This implies that the local fouling communities were either selecting for certain sized particles or adding particles between 1.5 and $5 \mu \mathrm{m}$ and greater than $25 \mu \mathrm{m}$ in diameter to the water column, possibly in the form of feces or pseudofeces. The starved communities showed uniform retention of particles over the entire size range

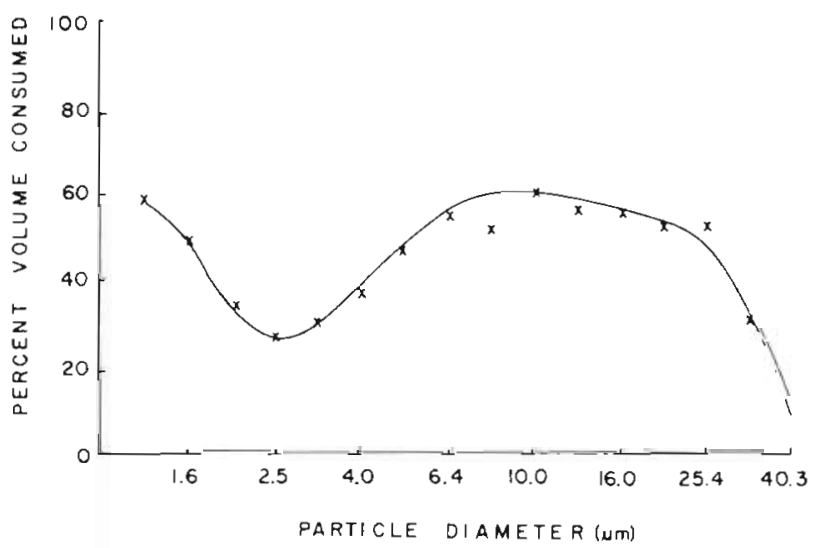

Fig. 1. Average percent of initial particle volume consumed by fouling communities submerged for $1 \mathrm{~h}$ in a test tank of river water for sizes of particles ranging from 1 to $40 \mu \mathrm{m}$

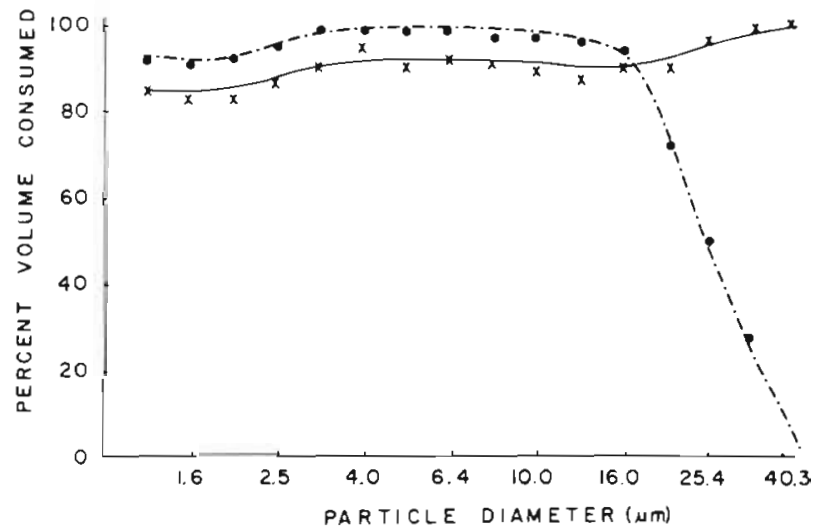

Fig. 2. Average percent of initial particle volume consumed by starved fouling communities after $2 \mathrm{~h}$ (solid line) and $4 \mathrm{~h}$ (broken line) for particles sizes of 1 to $40 \mu \mathrm{m}$ 
of particles counted (1-40 $\mu \mathrm{m}$; Fig. 2) for the first $2 \mathrm{~h}$ indicating that the local fouling community does not take up particles selectively. After $4 \mathrm{~h}$ there was an apparent decrease in retention of particles greater than $25 \mu \mathrm{m}$ suggesting that communities began to emit particles greater than $25 \mu \mathrm{m}$ after feeding for several hours.

When communities were put in filtered seawater to determine what sized particles were emitted, particle counts increased in particle size classes between 1.5 and $4 \mu \mathrm{m}$ and greater than $20 \mu \mathrm{m}$ after $2 \mathrm{~h}$ (Fig. 3). After $4 \mathrm{~h}$, only particle size classes larger than $20 \mu \mathrm{m}$ increased, suggesting that the community may have reconsumed the particles between 1.5 and $4 \mu \mathrm{m}$, and possibly reemitted them as larger size particles.

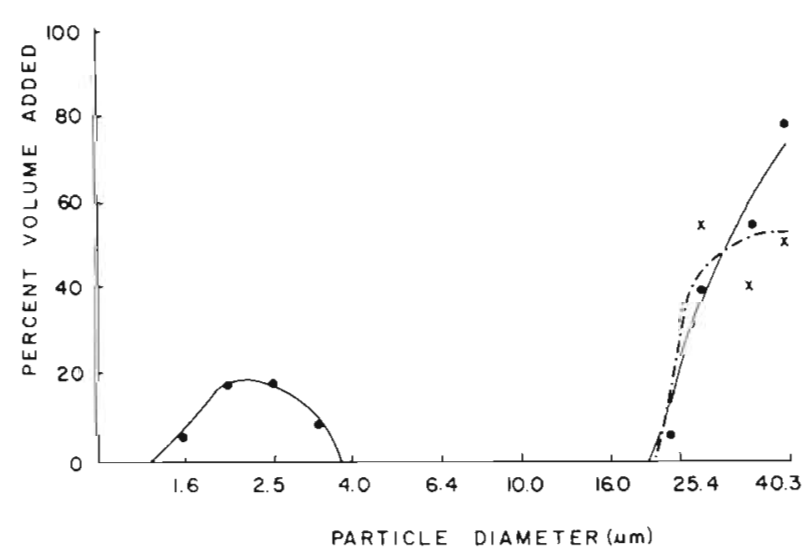

Fig. 3. Average percent increase from initial particle volume added to filtered seawater by fouling communities after $2 \mathrm{~h}$ (solid line) and $4 \mathrm{~h}$ (broken line) for particle sizes of 1 to $40 \mu \mathrm{m}$

The local fouling community can filter suspended material between 1 and $40 \mu \mathrm{m}$ in diameter. The collective community can filter smaller particles (less than $2 \mu \mathrm{m}$ ) than some ascidians (Randlov and Riisgard, 1979), bivalves (Mohlenberg and Riisgard, 1978) and salps (Harbison and McAlister, 1979). The fact that the community appeared to reconsume some of the particles that it had emitted indicates that particles emitted by some species may be reconsumed by other species in the community. This suggests that a community of suspension feeders consisting of many species may be able to utilize the suspended material food resource more efficiently than a suspension feeding community consisting of 1 or only a few species. This is because the more diverse community may recycle the same food particles through several species before the food falls to the bottom as detritus.

Acknowledgements. I would like to thank Charles Hoskin, Al Stoner and Robert Virnstein for critically reviewing this manuscript.

\section{LITERATURE CITED}

Harbison, G. R., McAlister, V L. (1979). The filter-feeding rates and particle retention efficiencies of three species of Cyclosalpa (Tunicata, Thaliacea). Limnol. Oceanogr. 2 (5): 875-892

Haven, D. S., Morales-Alamo, R. (1966). Aspects of biodesposition by oysters and other invertebrate filter feeders. Limnol. Oceanogr. 11: 487-498

Haven, D. S., Morales-Alamo, R. (1970). Filtration of particles from suspension by the American Oyster Crassostrea virginica. Biol. Bull. mar. biol. Lab., Woods Hole 139: 248-264

Jørgensen, C. (1966). Biology of suspension feeding, Pergamon Press, New York

Mohlenberg, F., Riisgard, H. (1978). Efficiency of particle retention in 13 species of suspension feeding bivalves. Ophelia 17 (2): 239-246

Mohlenberg, F., Riisgard, H. (1979). Filtration rate, using a new indirect technique, in thirteen species of suspensionfeeding bivalves. Mar Biol. 54: 143-147

Mook, D. H. (1976). Studies on fouling invertebrates in the Indian River 1. Seasonality of settlement. Bull. mar. Sci. 26 (4): $611-615$

Mook, D. H. (1980). Seasonal variation of species composition of recently settled fouling communities along an environmental gradient in the Indian River Lagoon. Florida. Estuar. coast. mar. Sci. 11: 573-581

Mook, D. H. (in press). Effects of disturbance and initial settlement on fouling community structure. Ecology

Randlov, A., Riisgard, H. (1979). Efficiency of particle retention and filtration rate in four species of Ascidians. Mar. Ecol. Prog. Ser. 1: 55-59

Riisgard, H. U. (1977). On measurements of the filtration rates of suspension feeding bivalves in a flow system. Ophelia $16(2): 167-173$

Riisgard, H. U., Mohlenberg, F. (1979). An improved automatic recording apparatus for determining the filtration rate of Mytilus edulis as a function of size and algal concentration. Mar. Biol. 52: 61-67

Rubenstein, D. T., Koehl, M. A. R. (1977). The mechanisms of filter feeding: some theoretical considerations. Am. Nat. 111 (981): 981-994

Winter, J. E. (1978). A review on the knowledge of suspension-feeding in Lamellibranchiate bivalves, with a special reference to artificial aquaculture systems. Aquaculture 13: 1-33 